\title{
Sustainable Utilization of Steel Slag from Traditional Industry and Agriculture to Catalysis
}

\author{
Di Gao, Fu-Ping Wang, Yi-Tong Wang *(1) and Ya-Nan Zeng * \\ College of Metallurgy and Energy, North China University of Science and Technology, 21 Bohai Street, \\ Tangshan 063210, China; gaodi1113@gmail.com (D.G.); fwang3692@gmail.com (F.-P.W.) \\ * Correspondence: wangyt@ncst.edu.cn (Y.-T.W.); zengyanan@ncst.edu.cn (Y.-N.Z.)
}

Received: 24 September 2020; Accepted: 4 November 2020; Published: 9 November 2020

\begin{abstract}
Steel slag is a large amount of residual material produced in the process of steel manufacturing. With the requirements of sustainable development in China, the utilization of steel slag has become a hot issue. Through an in-depth study on steel slag, it is apparent that it has been widely used in various fields in recent years. The resource utilization of steel slag is not only conducive to resource conservation, but also conducive to sustainable production and environmental protection. In this paper, the common ways of resource utilization of steel slag in construction, agriculture, industry, and catalysis are reviewed. Steel slag as a solid waste with great development potential and large output is expected to be widely developed into high value-added products such as catalytic material in the future.
\end{abstract}

Keywords: steel slag; resource utilization; utilization of solid waste; sustainable development; high value-added

\section{Introduction}

With the rapid development of China's steel industry, rising rates of steel production have led to the increase of steel slag emissions. Steel slag is a kind of industrial solid waste produced in the process of iron and steel smelting, and its emission is about $15 \mathrm{wt} \%-20 \mathrm{wt} \%$ of crude steel output [1]. According to the data released by the World Iron and Steel Association, China's crude steel output in 2019 was 996 million tons, which meant that the emission of steel slag was as high as 100 million tons, while the comprehensive utilization rate of steel slag in China was only about $25 \%$ [2]. The comprehensive utilization rate of steel slag in developed countries such as the United States, Japan, and Germany was almost 100\% [3]. Compared with developed countries, there was a lot of exploration space in the resource utilization of steel slag in China. Improving the utilization rate of steel slag and reducing the side effects of steel slag on environmental protection was the premise to ensure the green, stable, and sustainable development of the metallurgical industry [4].

In the process of iron and steel production, steel slag is mainly produced in the smelting process of raw metal ore, which is the slag discharged from the smelting process of converter, electric furnace, or refining furnace, and is mainly composed of oxides generated after the oxidation of various elements in the furnace charge, eroded lining materials, and added slagging materials [5]. Because of the different steel production processes and various raw materials, there are some differences in the composition of steel slag. Steel slag contains a variety of useful components: calcium oxide $(\mathrm{CaO})$, magnesium oxide $(\mathrm{MgO})$, silicon dioxide $\left(\mathrm{SiO}_{2}\right)$, alumina $\left(\mathrm{Al}_{2} \mathrm{O}_{3}\right)$, ferrous oxide $(\mathrm{FeO})$, iron oxide $\left(\mathrm{Fe}_{2} \mathrm{O}_{3}\right)$, manganese dioxide $\left(\mathrm{MnO}_{2}\right)$, free calcium oxide ( $\left.\mathrm{f}-\mathrm{CaO}\right)$, and free magnesium oxide (f-MgO). The main mineral phases are solid solutions of calcium silicate, dicalcium silicate, aurolite, calcium aluminoferrite, and oxides of silicon, magnesium, iron, manganese, and phosphorus, and also a small amount of free calcium oxide and metallic iron [6,7]. 
In summary, the complex composition and structure of steel slag determine the diversity of steel slag characteristics, so that steel slag can be used in many fields, such as cement, concrete aggregate, road paving, fertilizer production, and so on, and some achievements have been made, though the application of steel slag is limited in these aspects because of some negative factors. The catalytic performance of steel slag could be developed, which opens up a new way for the resource utilization of steel slag.

\section{Resource Utilization of Steel Slab}

\subsection{Production of Building Material}

Steel slag has the characteristics of high density, high strength, many pits on the surface, strong wear resistance, and gel property [8]. Therefore, steel slag can be used to prepare cement and steel slag bricks with little or no clinker, steel slag brick, concrete aggregate, and other building materials.

Steel slag contains a large number of active materials, such as $3 \mathrm{CaO} \cdot \mathrm{SiO}_{2}$ and $2 \mathrm{CaO} \cdot \mathrm{SiO}_{2}$, which are similar to the main components of a Portland cement clinker [9]. Therefore, in cement production, steel slag can be mixed into cement clinkers in a certain proportion to obtain steel slag cement, steel slag Portland cement, steel slag white cement, and other products [10]. Shan et al. used the principle that steel slag and blast furnace slag can activate each other to promote hydration and added a $25 \%$ steel slag and $25 \%$ blast furnace powder as an admixture to increase the strength of the cement, with results showing that the 28 day bending strength and compressive strength of cement was $21.2 \mathrm{MPa}$ and $55.0 \mathrm{MPa}$, respectively, which recently met the strength requirement of 52.5 grade Portland slag cement in GB/T175-2007 [11].

Liu et al. successfully prepared a new type of permeable brick for walkway-steel slag base permeable brick (SSPB) by liquid phase sintering and systematically studied the effect of sintering temperature on the properties of SSPB [12]. The results showed that SSPB had excellent permeability, high mechanical strength, bending strength, and excellent chemical stability at the optimum sintering temperature of $1270{ }^{\circ} \mathrm{C} / 1 \mathrm{~h}$. This study provides a kind of environmental protection permeable brick with high added value and provides an important guide for the utilization of industrial steel slag waste.

Steel slag contains more iron particles, loose structure, less pores, hard and dense texture, so that the steel slag has good compressive strength and rough surface. As coarse aggregate, it can make the bond between aggregate and cement stone better [13]. When the steel slag was used as the binder of the concrete, the fluidity among mud particles was improved, and the micro-aggregate effect was added so that the void ratio in the concrete was reduced, penetrating pores were difficult to form, and the impermeability of the concrete was improved. The latter strength, chloride ion permeability resistance, and carbonization resistance were all improved. Liu et al. used steel slag as a gel material, mixed 30\%, $50 \%$, and $70 \%$ steel slag into concrete by volume and tested the mechanical properties and durability of the mixture. When the cement content was $4 \%$ and the steel slag content was $50 \%$, its strength and stiffness were the largest [14]. As a kind of high activity admixture, steel slag powder played an important role in the preparation of high-performance concrete. Compared with limestone mixture, steel slag mixture had good economic benefits and potentially huge environmental benefits [15].

\subsection{Extraction of Various Valuable Components}

Steel slag is rich in the heavy metal element chromium, from which the separation of chromium is conducive to the realization of steel slag recycling and environmental protection, while alleviating the demand for chromium in China [16]. Mochizuki et al. studied the separation and recovery of metal elements from steel slag through a combination of chlorination and carbon chlorination, with their results showing that the combined method was effective for separating $\mathrm{Fe}, \mathrm{Ti}$, and $\mathrm{P}$ from steel slag [17]. 


\subsection{Agricultural Fertilizer Production}

Steel slag could also be used as a raw material for soil improvement and fertilizer production. The chemical composition of $\mathrm{CaO}, \mathrm{SiO}_{2}$, and $\mathrm{MgO}$ in steel slag was the same as that of the raw inorganic fertilizer material, in terms of composition and also contained effective components such as $\mathrm{FeO}$, $\mathrm{MnO}$, and $\mathrm{P}_{2} \mathrm{O}_{5}[18,19]$. The solubility of steel slag was improved by the high-temperature calcination that resulted from the process of smelting, so that the easily soluble amount of the main components reached $1 / 3-1 / 2$ of the total amount, part of which was even higher, and more easily absorbed by plants. Thus, steel slag was a fast and powerful compound mineral fertilizer [20] and was used to prepare phosphate fertilizer and silicon fertilizer.

Silicon could promote the yield of plants. There was a lot of active silicon in steel slag that could be absorbed by crops, so many researchers used steel slag as raw material to produce steel slag silicon fertilizer, which was mainly applicable to wheat, rice, corn, and sugarcane, among which rice was the most significant [21]. Steel slag was a good raw material for silicon-calcium fertilizer and acid soil amendment because of its large specific surface area and porosity [22]. Ning et al. studied the application of steel slag in soil, and their results suggested that it not only improved the $\mathrm{pH}$ value of soil but also increased the availability of silicon in soil, both of which were conducive to reducing the accumulation of $\mathrm{Cd}$ (cadmium) in rice buds or grains, helped to reduce the effective concentration of heavy metals, reduced the mobility of metals, and combined metals into more stable components [23].

Phosphorus could greatly promote the growth of crops. Steel slag phosphate fertilizer was made from basic steel slag by crushing and grinding. Its main components were $\mathrm{Ca}_{4}\left(\mathrm{PO}_{4}\right)_{2}, \mathrm{Ca}_{2} \mathrm{SiO}_{4}$, and some metal elements such as magnesium, iron, and manganese. For acid soil, steel slag phosphate fertilizer was an excellent base fertilizer, which could improve soil fertility. The release of steel slag phosphate fertilizer in soil was relatively slow and the after-effect was very good. When steel slag was selected as the additive of fused calcium-magnesium phosphate (FCMP), the content of soluble $\mathrm{SiO}_{2}$ and alkali in steel slag exceeded the requirement of the national standard, added to FCMP is good [24]. The application of steel slag could increase rice yield because it contained $\mathrm{CaO}, \mathrm{MgO}, \mathrm{P}_{2} \mathrm{O}_{5}$, and other elements, which effectively promoted the synthesis of rice [25].

Phosphate fertilizer with steel slag could be used for remediation of lead contaminated soil, which reduces the concentration of lead in soil by changing $\mathrm{pH}$, available phosphorus content, and chemical reaction [26]. The repair mechanism of phosphate fertilizer with steel slag included precipitation/coprecipitation and ion exchange adsorption. The $\mathrm{Ca}^{2+}$ in the steel slag phosphate fertilizer was replaced by $\mathrm{Pb}^{2+}$, and the formed lead phosphate precipitate had low solubility, good acid and alkali resistance, good chemical repair, and was extremely difficult to be decomposed under natural environments [27]. Zhang et al. preferred the kind of acid to be added by testing the $\mathrm{pH}$ value, resistivity, and $\mathrm{Ca}^{2+}$ dissolution of differently modified steel slag phosphate fertilizers [28]. In view of the low content of soluble phosphorus in ordinary steel slag phosphate fertilizers and the poor effect on the remediation of heavy metal pollutants, they modified the steel slag phosphate fertilizer to improve its remediation effect. When the initial concentration of $\mathrm{Pb}$ in the soil was not higher than $1000 \mathrm{mg} / \mathrm{kg}$, the remedying soil, with $15 \%$ and $20 \%$ of A-TP and N-TP, respectively, could meet the requirements after 7 days of curing. The use of A-TP is small and its economy is good.

\subsection{Terial}

Steel slag as metallurgical raw material, and its main value, was reflected in the sintering flux, blast furnace flux, and the return slag in the process of steel making. The flux of blast furnace and steel making was mostly limestone $(\mathrm{CaO})[29]$. Steel slag separated by magnetic separation contained a large amount of iron and magnetic iron oxide, which could be directly returned to the blast furnace to be smelted into steel, thus greatly saving the consumption of lime, shortening the slag-forming time of steel slag, and improving the fluidity of molten slag. Developed countries, such as the USA, Japan, and Germany, use steel slag as sintering material to be returned to blast furnace for reuse, and the effect is considerable, accounting for $24 \%-75 \%$ of the comprehensive utilization of steel slag [30]. Steel slag 
replaced limestone as a metallurgical raw material, thus reducing metallurgical fuel consumption and metallurgical production costs, and improving blast furnace operation status [31].

With the development of the economy and the increase of steel production, the discharge of steel slag is increasing. Under the current mode of steel slag utilization, the development and application of domestic steel slag resource technology has made some achievements, and the effective utilization of steel slag has been realized to a certain degree. At present, steel slag is mainly used as a cement concrete admixture, soil improvement fertilizer, and for building materials in China, but the utilization rate is only about $25 \%$, which is far behind that of other developed countries. The main reasons why China's steel slag resources have not been used on a large scale and with high efficiency are as follows: (i) There is $\mathrm{f}-\mathrm{CaO}$ (free calcium oxide) and a small amount of $\mathrm{f}-\mathrm{MgO}$ (free magnesium oxide) in steel slag. These substances cause a hydration reaction, resulting in volume expansion, thus greatly limiting the utilization of steel slag for building materials. In order to eliminate the volume stability problems caused by $\mathrm{f}-\mathrm{CaO}$ and $\mathrm{f}-\mathrm{MgO}$, it is necessary to modify the steel slag, which greatly increases the cost [32,33]; (ii) because there are a large number of micron-sized metallic iron particles in steel slag, it causes a high energy consumption of steel slag grinding. At the same time, steel slag has low activity, which greatly limits the application of steel slag in cement or gel [34]; (iii) When steel slag is used as a soil conditioner and as a chemical fertilizer, some heavy metal elements contained in steel slag may cause secondary pollution of the soil.

\subsection{Pyrolysis}

The experiment of $\mathrm{CO}_{2}$ catalytic pyrolysis of polystyrene on steel slag was carried out by Lee et al. In the presence of a steel slag catalyst, the ability of dehydrogenation of hydrocarbons to $\mathrm{H}_{2}$ was greatly improved. Since $\mathrm{CO}_{2}$ could be used as an oxidant in the presence of steel slag, the synergistic effect of steel slag and $\mathrm{CO}_{2}$ resulted in a more than 300-fold increase in $\mathrm{CO}$ production and a doubling of $\mathrm{H}_{2}$ production [35]. Cho et al. used scrap tire (ST) as raw material to pyrolyze ST in a $\mathrm{CO}_{2}$ atmosphere, and the effect was significantly enhanced (about $400 \%$ at $400{ }^{\circ} \mathrm{C}$ ). In the presence of steel slag, $\mathrm{CO}_{2}$ enhanced the pyrolysis of volatile pyrolysis compounds and promoted the formation of $\mathrm{H}_{2}$ [36]. Lee et al. used pine sawdust as the carbonaceous material for pyrolysis and controlled the pyrolysis of carbon from a liquid state to a gas state through gas phase reactions (GPRS). Using steel slag as a catalyst, the slow reaction kinetics of $\mathrm{CO}_{2}$ with GPRS of volatile pyrolysis products was obviously accelerated, resulting in the enhancement of $\mathrm{CO}$ and the formation of $\mathrm{CH}_{4}$ and $\mathrm{H}_{2}$ [37]. Kim et al. carried out a pyrolysis of biogas residue under the condition of $\mathrm{CO}_{2}$. The metal elements in the steel slag accelerated the homogeneous reaction in the catalysis, which significantly accelerated the reaction kinetics, and increased the production of $\mathrm{CO}$, thus promoting the rapid increase of $\mathrm{H}_{2}$ and $\mathrm{CH}_{4}$ production and producing more pyrolysis gas [38]. Kapird et al. used steel slag derived zeolite (FAU-SL) to catalyze the pyrolysis of oil palm mesocarp fiber (OPMF) in a slow heating fixed bed reactor. At $550{ }^{\circ} \mathrm{C}$, the maximum yield of bio oil was $47 \mathrm{wt} \%$, the relative abundance of peak area was $48.02 \%$, and the peak area of phenolic compounds was $12.03 \%$. Compared with other common zeolites, the activity of the catalyst narrowed the distribution range of organic compounds in bio oil [39].

\subsection{Tar Cracking}

Metal oxides such as $\mathrm{Fe}_{2} \mathrm{O}_{3}, \mathrm{MgO}$ and $\mathrm{Al}_{2} \mathrm{O}_{3}$ in steel slag may promote the catalytic tar reforming process. Guo et al. used steel slag calcined with a small amount of nickel at $900{ }^{\circ} \mathrm{C}$ and then carried out biomass catalytic reforming experiments to pyrolyze pine sawdust to produce primary tar [40]. The calcined steel slag formed granular $\mathrm{NiO}$ particles that were dispersed on the surface of nickel bearing steel slag to form a porous catalyst, which provided conditions for a long-term and effective application of a steel slag supported catalyst in the biomass tar reforming process. Li et al. proposed a method of coupling a catalytic thermochemical conversion of oily sludge with a high-temperature reduction of steel slag [41]. The results showed that temperature, slag addition, and slag particle fineness were positively correlated with gas production rate, iron reduction rate, and carbon conversion 
rate. With the addition of steel slag, the carbon conversion rate increased from $76.6 \%$ to $90.1 \%$, and the reduced iron efficiency increased from $38.5 \%$ to $70.6 \%$. As an effective catalyst for a cracking/reforming reaction, iron particles in situ could produce significant fuel gas, which improved the reduction rate of steel slag and the catalytic cracking/reforming rate of oily sludge. Song et al. studied whether steel slag could be used as a catalyst for oil sludge pyrolysis. Their results showed that steel slag as a catalyst could increase the $\mathrm{H}_{2}$ content in the pyrolysis of oil sludge pyrolysis process [42]. The addition of steel slag promoted the fracture of macromolecules and reduced the activation energy of oil sludge pyrolysis, which played a good role in promoting pyrolysis.

In conclusion, through the process of biomass pyrolysis, metal elements rich in steel slag could form effective active structures after modification, so as to prevent the formation of a stable chemical structure in hydrocarbon and accelerate hydrocarbon degradation. As a catalyst, steel slag could promote the decomposition of tar by weakening the $\mathrm{C}-\mathrm{C}$ bond, thus reducing the activation energy of a complex pyrolysis reaction. Furthermore, it may have a good catalytic effect on the pyrolysis of biomass tar.

\subsection{Optical Induction}

Steel slag could be used as photocatalyst to degrade organic matter. Kang et al. synthesized a new porous steel slag-based cementitious material photocatalyst by a $\mathrm{CeO}_{2}$ impregnation method [43]. Adding a pore-forming agent to change the pore structure, the mass transfer rate of water molecules increased, and the coupling semiconductor formed by the highly dispersed active $\mathrm{CeO}_{2}$ component and $\mathrm{FeO}$ in the carrier promoted the efficient separation of photogenerated electron and hole pairs, thus improving the catalytic activity of the whole photocatalytic system. Sarkar et al. synthesized a MIL-53 (FE)/SiO 2 nanocomposite photocatalyst with a simple solvothermal method using steel slag as raw material and carried out photodegradation experiments of methylene blue (MB) under different conditions [44]. The UV-Vis absorption spectra and PL spectra showed that it had a good photocatalytic activity in the UV region. Under UV irradiation, the degradation rate reached $66.3 \%$ when the amount of photocatalyst was $0.5 \mathrm{~g} / \mathrm{L}$, which was much higher than that of similar catalysts. Zhang et al. reported a new type of nickel calcium cementitious material through alkali steel slag polymerization and ion exchange reactions and carried out a photocatalytic degradation of MB [45]. In the process of photocatalytic oxidation and degradation, $\mathrm{Ni}^{2+}$ ions played an important role in the transfer of photo-induced electrons, while iron oxide was responsible for the transfer of a photogenerated electron-hole, thus improving the separation efficiency of electron hole pairs and improving the photocatalytic efficiency. Shao et al. reported a steel slag derivative of calcium silicate hydrate (CSH) with a hierarchical structure and amorphous phase using an alkali activation method, which is used for in situ photodegradation of the organic pollutant MB [46]. The adsorption capacity of all heavy metals was higher than $100 \mathrm{mg} / \mathrm{g}$, and the photodegradation efficiency of MB under low-power visible light was $63 \%$. The results showed that CSH, a derivative of steel slag, had excellent chemical adsorption and in situ photodegradation of organic pollutants.

\subsection{Electrocatalysis}

Wang et al. made a new particle electrode with steel slag. The results showed that the new particle electrode had good catalytic activity for the degradation of rhodamine B (RhB) in three-dimensional electrolytic cells [47]. In $60 \mathrm{~min}, 82.4 \%$ and $65.54 \%$ of RhB were removed with and without aeration, respectively, which was much higher than $42.4 \%$ of $\mathrm{RhB}$ in the same time and had good circulation performance. It was feasible and economical to use steel slag as a particle electrode. Zhang et al. prepared a kind of Sn/Mn loaded steel slag zeolite particle electrode and applied it to the three-dimensional electrocatalytic system (TDE) degradation of RhB. Under the optimal conditions, the degradation rate of RhB in TDE reached 95.0\% [48]. Wang et al. prepared a reactor with a saturation magnetic field of $1.6389 \mathrm{emu} / \mathrm{g}$. Magnetic steel slag particles were used as particle electrodes to promote the degradation of organic matter, and $85 \%$ of total organic carbon (TOC) could be removed in $2 \mathrm{~h}$ 
under the optimal conditions [49]. The magnetic particle electrode maintained a high TOC removal efficiency in the novel continuous three-dimensional reactor and had a good practical application potential. Song et al. prepared particle electrodes with kaolin/steel slag as raw materials to degrade methylene blue (MB) [50]. Under the optimum conditions, the degradation rate of MB decreased from $87.0 \%$ to $81.2 \%$. The results showed that the electrocatalytic activity of three-dimensional electrodes was much better than that of two-dimensional electrochemical reactors. In addition, it was provem that the kaolin/steel slag particle electrode had good cycle performance. Teng et al. prepared a kind of particle electrode to degrade MB. Under the best combination of $\mathrm{pH} 3$, voltage $12 \mathrm{~V}$, initial $\mathrm{MB}$ concentration $15 \mathrm{mg} / \mathrm{L}$, electrolyte concentration $0.3 \mathrm{~mol} / \mathrm{L}$, the removal rate of $\mathrm{MB}$ reached $91.41 \%$ [51]. The results showed that the removal efficiency of MB by three-dimensional electrodes was $23.48 \%$ higher than that by two-dimensional electrode, and energy consumption was reduced by $36.2 \%$.

\section{Conclusions}

At present, steel slag is mainly used in construction, agriculture, and other fields. In the field of construction, steel slag is often used in cement, steel slag brick, and concrete aggregate due to its poor stability, low activity, and other adverse factors. According to a certain proportion and other materials mixed to achieve the use of the standard, there are certain restrictions. In agriculture and other fields, soil improvement and fertilizer production have achieved some results, but the problem of secondary pollution caused by heavy metals needs to be further solved. Compared with other developed countries, the application of industrial recycling has yet to be further explored. Steel slag as a catalyst has a broad prospect in the field of catalytic pyrolysis, tar cracking, photocatalysis, and electrocatalysis, and other aspects have shown high efficiency catalytic performance. In some catalytic aspects used for pyrolysis and tar cracking, steel slag can synergistically interact with some substances to form a virtuous cycle, and its catalytic performance is greatly improved.

In conclusion, steel slag as a catalyst has the characteristics of high efficiency, economy, and reusability and will not be affected by the bad factors. In addition to construction, the agricultural industry, and other fields, application of steel slag in catalysis has great potential, which provides more development space for the green sustainable utilization of steel slag in China.

Author Contributions: Conceptualization, Y.-T.W.; Writing—original draft preparation, D.G.; Writing—review and editing, F.-P.W., Y.-T.W. and Y.-N.Z.; Funding acquisition, Y.-T.W. and Y.-N.Z. All authors have read and agreed to the published version of the manuscript.

Funding: The authors wish to acknowledge the financial support from National Natural Science Foundation of China (No: 52004095 and 51704119) and Natural Science Foundation of Hebei Province (E2017209243) and Department of Education of Hebei Province (BJ2019038).

Acknowledgments: The authors give thanks to the anonymous reviewers and all the editors in the process of manuscript revision.

Conflicts of Interest: The authors declare no conflict of interest.

\section{References}

1. Yi, H.; Xu, G.; Cheng, H.; Wang, J.; Wan, Y.; Chen, H. An Overview of Utilization of Steel Slag. Procedia Environ. Sci. 2012, 16, 791-801. [CrossRef]

2. Guo, J.; Bao, Y.; Wang, M. Steel slag in China: Treatment, recycling, and management. Waste Manag. 2018, 78, 318-330. [CrossRef] [PubMed]

3. Chen, K.Q. The Discussion on the Status Quo and Development Trend of Solid Waste Utilization in Iron and Steel Enterprises. Iron Steel Scrap Chin. 2018, 5, 33-36.

4. Yang, C.L.; Yao, J.B.; Yuan, J. Comprehensive utilization of converter steel slag in concrete paving bricks. Block Brick Tile 2018, 365, 68-70.

5. Tsakiridis, P.; Papadimitriou, G.; Tsivilis, S.; Koroneos, C. Utilization of steel slag for Portland cement clinker production. J. Hazard. Mater. 2008, 152, 805-811. [CrossRef] [PubMed] 
6. Liu, F. Comprehensive Utilization of Steel Slag from Solid Waste of Metallurgical Industry. Chin. Resour. Compr. Util. 2019, 37, 73-75.

7. Ramezanianpour, A.A.; Kazemian, A.; Moghaddam, M.A.; Moodi, F.; Ramezanianpour, A.M. Studying effects of low-reactivity GGBFS on chloride resistance of conventional and high strength concretes. Mater. Struct. 2015, 49, 2597-2609. [CrossRef]

8. Sun, Y.; Zhang, Z.; Liu, L.; Wang, X. Multi-Stage Control of Waste Heat Recovery from High Temperature Slags Based on Time Temperature Transformation Curves. Energies 2014, 7, 1673-1684. [CrossRef]

9. Liu, W.; Li, H.; Zhu, H.; Xu, P. Properties of a Steel Slag-Permeable Asphalt Mixture and the Reaction of the Steel Slag-Asphalt Interface. Materials 2019, 12, 3603. [CrossRef]

10. Li, C.; Chen, Z.W.; Xie, J.; Wu, S.P.; Xiao, Y. A Technological and Applicational Review on Steel Slag Asphalt Mixture. Mater. Rev. 2017, 31, 86-95.

11. Shan, J.H.; Wang, Z.; Ji, S.X.; Mao, K.; Lian, S.Q. Experimental investigation on steel slag as cement mixture. N. Build. Mater. 2020, 47, 53-56.

12. Liu, J.; Lin, C.; Liu, T.; Han, L.; Shen, X.; Li, C.; Lu, A. An eco-friendly permeable brick with excellent permeability and high strength derived from steel slag wastes. Int. J. Appl. Ceram. Technol. 2019, 17, 584-597. [CrossRef]

13. He, Z.H.; Zhang, X.X.; Zhan, P.M.; Yang, Y.F. Research progress of steel slag powder and its effect on the properties of cement-based materials. Concrete 2020, 2, 83-89, 93.

14. Liu, J.; Yu, B.; Wang, Q. Application of steel slag in cement treated aggregate base course. J. Clean. Prod. 2020, 269, 121733. [CrossRef]

15. Maghool, F.; Arulrajah, A.; Horpibulsuk, S.; Du, Y.-J. Laboratory Evaluation of Ladle Furnace Slag in Unbound Pavement-Base/Subbase Applications. J. Mater. Civ. Eng. 2017, 29, 04016197. [CrossRef]

16. Ma, S.J.; Liu, S.Y.; Hu, Z.L.; Chen, J.X.; Lin, M.Q. Study on the Adsorption Characteristics of Heavy Metal Ions Chromium(III) and Lead on Steel Slag Adsorbent. Non Ferr. Min. Metall. 2004, 20, 57-59.

17. Mochizuki, Y.; Tsubouchi, N.; Sugawara, K. Separation of valuable elements from steel making slag by chlorination. Resour. Conserv. Recycl. 2020, 158, 104815. [CrossRef]

18. Shi, C. Steel Slag-Its Production, Processing, Characteristics, and Cementitious Properties. J. Mater. Civ. Eng. 2004, 16, 230-236. [CrossRef]

19. Radić, S.; Crnojević, H.; Sandev, D.; Jelić, S.; Sedlar, Z.; Glavaš, K.; Pevalek-Kozlina, B. Effect of Electric Arc Furnace Slag on Growth and Physiology of Maize (Zea mays L.). Acta Biologica Hungarica 2013, 64, 490-499. [CrossRef]

20. Pang, C.L.; Yang, X.Q.; Song, J.G.; Liu, R.J. Research status and development trend of comprehensive utilization of steel slag. Block Brick Tile 2020, 3, 77-80. [CrossRef]

21. Soratto, R.P.; Fernandes, A.M.; Pilon, C.; Souza, M.R. Phosphorus and silicon effects on growth, yield, and phosphorus forms in potato plants. J. Plant Nutr. 2018, 42, 218-233. [CrossRef]

22. Gao, J.-T.; Li, S.-Q.; Zhang, Y.-T.; Zhang, Y.; Chen, P.-Y.; Shen, P. Process of Re-Resourcing of Converter Slag. J. Iron Steel Res. Int. 2011, 18, 32-39. [CrossRef]

23. Ning, D.; Liang, Y.; Liu, Z.; Xiao, J.; Duan, A. Impacts of Steel-Slag-Based Silicate Fertilizer on Soil Acidity and Silicon Availability and Metals-Immobilization in a Paddy Soil. PLoS ONE 2016, 11, e0168163. [CrossRef] [PubMed]

24. Liu, H.Y. Steel slag is the optimum additive for FCMP. Phosphate Compd. Fertil. 2010, 25, 35-36.

25. Tong, Q.; Zhang, X.S.; Wei, X.M.; Shen, Y.; Ji, W.W. Effects of Slag Mucks and FCMP Combined Application on Rice Yield and Cd Content in Planting. North Rice 2011, 41, 6-9.

26. Han, F.; Yun, S.; Zhang, C.; Xu, H.; Wang, Z. Steel slag as accelerant in anaerobic digestion for nonhazardous treatment and digestate fertilizer utilization. Bioresour. Technol. 2019, 282, 331-338. [CrossRef]

27. Ning, D.F.; Liu, Z.D.; Xiao, J.F.; Liu, Z.G.; Zhao, B.; Qin, A.Z.; Nan, J.Q. Effects of Application of Steel Slag-based Silicon Fertilizer on Chemical Forms of Soil Silicon and Rice Growth. J. Irrig. Drain. 2016, 35, 42-46.

28. Zhang, K.; Han, J.J. Lead-contaminatedsoils Stabilized by Modified Thomas Phosphate. J. Xihua Univ. (Nat. Sci. Ed.) 2018, 37, 29-33.

29. Su, X.; Zhu, J.; Fu, Q.; Zuo, J.; Liu, Y.; Hu, H. Immobilization of lead in anthropogenic contaminated soils using phosphates with/without oxalic acid. J. Environ. Sci. 2015, 28, 64-73. [CrossRef] 
30. Wang, H.-T.; Zhao, W.; Chu, M.-S.; Feng, C.; Liu, Z.; Tang, J. Current status and development trends of innovative blast furnace ironmaking technologies aimed to environmental harmony and operation intellectualization. J. Iron Steel Res. Int. 2017, 24, 751-769. [CrossRef]

31. Jiang, Y.; Ling, T.C.; Shi, C.J.; Pan, S.Y. Characteristics of steel slags and their use in cement and concrete-A review. Resour. Conserv. Recycl. 2018, 136, 187-197. [CrossRef]

32. Wang, C.; Yang, J.L.; Zhu, G.L.; Hao, Y.D.; Zhang, Y.; Sun, S.S. The present situation and development in technology of iron and steel slag utilization with high-value addition. In Proceedings of the Ninth International Conference on Molten Slags, Fluxes and Salts (MOLTEN12), Beijing, China, 27-30 May 2012; pp. 1-14.

33. Wang, G.; Wang, Y.; Gao, Z. Use of steel slag as a granular material: Volume expansion prediction and usability criteria. J. Hazard. Mater. 2010, 184, 555-560. [CrossRef]

34. Singh, S.K.; Jyoti; Vashistha, P. Development of newer composite cement through mechano-chemical activation of steel slag. Constr. Build. Mater. 2020, 121147, in press. [CrossRef]

35. Lee, T.; Jung, S.; Park, Y.-K.; Kim, T.; Wang, H.; Moon, D.H.; Kwon, E.E. Catalytic Pyrolysis of Polystyrene over Steel Slag under $\mathrm{CO}_{2}$ Environment. J. Hazard. Mater. 2020, 395, 122576. [CrossRef] [PubMed]

36. Cho, S.-H.; Oh, J.-I.; Jung, S.; Park, Y.-K.; Tsang, Y.F.; Ok, Y.S.; Kwon, E.E. Catalytic pyrolytic platform for scrap tires using CO2 and steel slag. Appl. Energy 2020, 259, 114164. [CrossRef]

37. Lee, S.; Kim, S.-H.; Jung, S.; Park, Y.-K.; Tsang, Y.F.; Kwon, E.E. Use of steel slag as a catalyst in $\mathrm{CO}_{2}$-cofeeding pyrolysis of pine sawdust. J. Hazard. Mater. 2020, 392, 122275. [CrossRef]

38. Kim, J.-H.; Oh, J.-I.; Tsang, Y.F.; Park, Y.-K.; Lee, J.; Kwon, E.E. $\mathrm{CO}_{2}$-assisted catalytic pyrolysis of digestate with steel slag. Energy 2020, 191, 116529. [CrossRef]

39. Kabir, G.; Mohd Din, A.T.; Hameed, B.H. Pyrolysis of oil palm mesocarp fiber catalyzed with steel slag-derived zeolite for bio-oil production. Bioresour. Technol. 2018, 249, 42-48. [CrossRef]

40. Guo, F.; Zhao, X.; Peng, K.; Liang, S.; Jia, X.; Qian, L. Catalytic reforming of biomass primary tar from pyrolysis over waste steel slag based catalysts. Int. J. Hydrog. Energy 2019, 44, 16224-16233. [CrossRef]

41. Li, P.; Zhang, X.; Wang, J.; Guo, H.; Chen, Y.; Wang, Z.; Yan, B.; Chen, D. Process characteristics of catalytic thermochemical conversion of oily sludge with addition of steel slag towards energy and iron recovery. J. Environ. Chem. Eng. 2020, 8, 103911. [CrossRef]

42. Song, Q.; Zhao, H.; Jia, J.; Zhang, F.; Wang, Z.; Lv, W.; Yang, L.; Zhang, W.; Zhang, Y.; Shu, X. Characterization of the products obtained by pyrolysis of oil sludge with steel slag in a continuous pyrolysis-magnetic separation reactor. Fuel 2019, 255, 115711. [CrossRef]

43. Kang, L.; Zhang, Y.J.; Zhang, L.; Zhang, K. Preparation, characterization and photocatalytic activity of novel CeO loaded porous alkali-activated steel slag-based binding material. Int. J. Hydrog. Energy 2017, 42, 17341-17349. [CrossRef]

44. Sarkar, C.; Basu, J.K.; Samanta, A.N. Synthesis of MIL-53(Fe)/SiO 2 composite from LD slag as a novel Photo-catalyst for Methylene Blue degradation. Chem. Eng. J. 2019, 377, 119621. [CrossRef]

45. Zhang, Y.J.; Liu, L.C.; Xu, Y.; Wang, Y.C.; Xu, D.L. A new alkali-activated steel slag-based cementitious material for photocatalytic degradation of organic pollutant from waste water. J. Hazard. Mater. 2012, 146-150. [CrossRef]

46. Shao, N.; Li, S.; Yan, F.; Su, Y.; Liu, Z.; Zhang, Z. An all-in-one strategy for the adsorption of heavy metal ions and photodegradation of organic pollutants using steel slag-derived calcium silicate hydrate. J. Hazard. Mater. 2019, 382, 121120. [CrossRef]

47. Wang, Z.; Qi, J.; Feng, Y.; Li, K.; Li, X. Preparation of catalytic particle electrodes from steel slag and its performance in a three-dimensional electrochemical oxidation system. J. Ind. Eng. Chem. 2014, 20, 3672-3677. [CrossRef]

48. Zhang, Z.; Feng, Y.; Liu, N.; Zhao, Y.; Wang, X.; Yang, S.; Long, Y.; Qiu, L. Preparation of Sn/Mn loaded steel slag zeolite particle electrode and its removal effect on rhodamine B(RhB). J. Water Process. Eng. 2020, 37, 101417. [CrossRef]

49. Wang, Z.; He, X.; Li, J.; Qi, J.; Zhao, C.; Yang, G. Preparation of magnetic steel-slag particle electrode and its performance in a novel electrochemical reactor for oilfield wastewater advanced treatment. J. Ind. Eng. Chem. 2018, 58, 18-23. [CrossRef] 
50. Song, B.; Wang, Z.; Li, J.; Ma, Y. Preparation and electrocatalytic properties of kaolin/steel slag particle electrodes. Catal. Commun. 2020, 148, 106177. [CrossRef]

51. Teng, X.; Li, J.; Wang, Z.; Liu, W.; Song, D.; Chun, Z.; Deng, X. Treatment of Methyl Blue Wastewater by Steel Slag Particle Three-Dimensional Electrode System. Sci. Adv. Mater. 2020, 12, 344-349. [CrossRef]

Publisher's Note: MDPI stays neutral with regard to jurisdictional claims in published maps and institutional affiliations.

(C) 2020 by the authors. Licensee MDPI, Basel, Switzerland. This article is an open access article distributed under the terms and conditions of the Creative Commons Attribution (CC BY) license (http://creativecommons.org/licenses/by/4.0/). 